\title{
The Relationship between Attachment Styles in Adulthood and Attitudes towards Filial Responsibility: A Comparison between Three Generations of Arabs and Jewish Women
}

\author{
Pnina Ron \\ School of Social Work, University of Haifa, Haifa, Israel \\ Email: pitzyron@research.haifa.ac.il \\ Received 8 February 2016; accepted 29 May 2016; published 1 June 2016 \\ Copyright (C) 2016 by author and Scientific Research Publishing Inc. \\ This work is licensed under the Creative Commons Attribution International License (CC BY). \\ http://creativecommons.org/licenses/by/4.0/

(c) (i) Open Access

\begin{abstract}
Background: Care giving for an elderly parent is a universal developmental task, and in all societies is one of the women tasks; its expectations are considered norms known as filial responsibility. The aim of the study is to examine the possibility of connections between the attitudes toward filial responsibility to elderly parents and the attachment style in adulthood and age (generation) among women. Methods: The research participants were 63 Jewish and Arab university students, their mothers $(N=62)$ and their grandmothers $(N=63)$. Research instruments consisted of a selfreport questionnaire, which revealed background characteristics, and measured attitudes toward filial responsibility, style of adult attachment; self-esteem; sense of mastery and, family support. Results revealed ethnicity differences as well as between-generations differences regarding normative attitudes toward filial responsibility, which may indicate a changing taking place in the Arab society's approach concerning these attitudes. An additional finding brought to light the cross-generational differences in the relationship between the attachment style in adulthood and the attitudes regarding filial responsibility. Conclusion: It seems that in attitudes towards filial responsibility, Arab society is still traditional in terms of its approach to the institutions of clan and family mostly among the elderly Arab Muslims. All of the modern changes most likely have an effect on adults' sense of filial responsibility, on social norms, and on familial traditions.
\end{abstract}

\section{Keywords}

Filial Responsibility, Attitudes, Cultural Differences, Well-Being

How to cite this paper: Ron, P. (2016). The Relationship between Attachment Styles in Adulthood and Attitudes towards Filial Responsibility: A Comparison between Three Generations of Arabs and Jewish Women. Psychology, 7, 741-752. 


\section{Introduction}

Filial responsibility refers to the obligations of offspring to meet the needs of their elderly parents without remuneration or coercion, as perceived by the adult children and their parents. The "Filial responsibility" term is generally understood to refer to special duties that offspring must provide to their elderly parents beginning with the attitudes towards these obligations, services and specific actions of caring providing etc. Most of the social gerontology studies of on offspring caring for their elderly parent have focused on the traditional role of daughters as the main provider (Ron, 2009). Moreover, the grontological literature testifies that most middle-aged women will experience some form of caregiving to an aging parent at some point in life. Barusch and Spaid (1989) claimed that daughters take on a stereotypically feminine caregiving role, which creates some difficult circumstances, unique to women who take care for their elderly parents and in all societies these expectations are considered norms known as the women filial responsibility One way to explain this phenomenon might be connected to the sense of responsibility acquired by these women towards their elderly family members. Troll, Miller and Atchley (1979) defined this as the Cassandra Complex.

One of the theories that underlined the development of the filial responsibility concept is the lifespan theory (Baltes \& Graf, 1996). Regarding the responsibility of caring for the parent, Blenkner (1965) introduced the concept of filial maturity to describe the transition of the adult child from being relatively separate from the parents to becoming a source of support. This transition includes a change of perspective, which enables adult children to see their parents as vulnerable human beings.

Cicirelli (1988) suggested a developmental framework for understanding the idea of filial responsibility, based on the concept of caregiving anxiety. According to this framework, filial responsibility develops when children become anxious about their ability to successfully manage the responsibilities of caring for the parents, in the years to come- when the need arises. In addition, Cicirelli' suggested a filial responsibility model based on the attachment theory named "the Adult Attachment Model of Helping” (Cicirelli, 1993).

Attachment refers to an internal state, a desire to be close to the figure who provides a sense of comfort and security, and whose departure creates a sense of distress. The attachment figure does not fade in adulthood; rather, the need for closeness and contact with the attachment figure exists on a symbolic level, and is addressed through thoughts and fantasies. In situations of stress, the adult child might still turn to the attachment figure for various kinds of help, ranging anywhere from financial to emotional support (Cicirelli, 2010; Cicirelli, 1993; Karantzas, Evans, \& Foddy, 2010). Sörensen, Webster, \& Roggman (2002) found that the ways in which adult children are considerate of their parents' future needs is related to the type of attachment that was formed earlier between the adult child and the older parent. Young adults still see their parents as a source of support and seek parental advice, thus preserving to a certain extent the parent's function as an attachment figure. Later in life, both the child and the parent shift their security base to other sources and figures, spouses and partners, in the majority of cases (Merz, Schuengel, \& Schulze, 2008). Another process that is likely to take place is a change in the direction of the attachment relationship, such that the children, who used to rely on the parents for security and support, become a source of security and support for their parents (Krause \& Haverkamp, 1996; Grundy \& Henretta, 2006; Merz et al., 2008).

The type of attachment is perceived as the intersection of two orthogonal dimensions: attachment anxiety and attachment avoidance. An anxiety attachment style predicts caring for the elderly parent (Cicirelli, 1988). Adult children with an anxiety attachment style demonstrate a higher degree of willingness to provide future care for the parent (Cicirelli, 1993; Sörensen et al., 2002). It was also found that this attachment style increases the tendency of adult children to protect, care, and attend to their elderly parents (Karantzas et al., 2010). Yet, as regards the anxiety type of attachment, findings are mixed. Some claim that no association was found between adult children's anxiety attachment style and either current or planned future care for elderly parents (Karantzas et al., 2010). In contrast, there are researchers who have found a positive connection between anxiety attachment and caring for an elderly parent, albeit these cases demonstrated the provision of low-quality care. Anxiety attachment is an obstacle to the rendering of care for the elderly parent, and inappropriate care could be caused by self-centered anxieties experienced by the anxious adult child related to the shifting of attention from the self to the attachment figure (Feeney \& Hohaus, 2001; Collins \& Feeney, 2000; Karantzas et al., 2010).

Attachment avoidance refers to the degree to which a person fails to trust or feels suspicious and uncomfortable in close situations and consequently maintains physical and emotional distance from the attachment figures. The avoidance attachment style was found consistently to have a negative association with caring for elderly 
parents (Carpenter, 2001; Collins \& Feeney, 2000) and negatively associated with the desire to provide future care (Karantzas et al., 2010). The discomfort felt by adults with this attachment style, their avoidance of intimacy, their exaggerated self-reliance, and their lack of empathy moderate the ability to provide responsive and sensitive care (Gillath, Shaver, Mikulincer, Nitzberg, Erez, \& Van Ijzendoorn, 2005; Mikulincer \& Shaver, 2007).

The current study focuses on additional variables that are mentioned in the literature as related to and influencing adult children's tendency to provide help and support to their older parents. These variables are the intrapersonal variables (sense of mastery, self-esteem) and the interpersonal variable of family support.

Sense of mastery is the degree to which a person perceives having control over changes and life events (Lachman \& Weaver, 1998; Pearlin, 1999). The research literature indicates the existence of a positive relationship between one's sense of mastery over life events and the extent and quality of the care offered to one's older parents (Skaff, Pearlin, \& Mullen, 1996).

Self-esteem is one component within the concept of the self. Rosenberg defined it as encompassing the thoughts and feelings individuals have when perceiving themselves as objects (Rosenberg, 1965). A high sense of self-esteem was found to be related to higher levels of perceived mental wellbeing among adults caring for their family members compared to the levels found among adults who were not caring for family members (Chappell \& Reid, 2002; Ron, 2009).

Among the informal sources of interpersonal support, the literature presents family, friends, and significant others as significant sources of support (Hobfoll, 1996). Family support has been shown to have positive effects on mental wellbeing, on physical and mental health, and on adaptability (Cohen \&Willis, 1985; Ron, 2009).

Norms and filial attitudes are relevant to people in any stage of adulthood, from adolescence to old age. Hence, there is variance among the norms and attitudes, which stems from-among other variables-social characteristics, such as age, education and the family status of the adult children as well as that of their parents. In addition, the research literature has identified social characteristics that differentiate people. For example, although the attitudes that young adults express about caring for an older parent are well entrenched, there is evidence that the tendency to care for older parents diminishes over the years (Silverstein \& Gans, 2006). This tendency can explained by the simple fact that from the point of view of young adults, the need to care for their parents is a distant prospect and, consequently, they tend to idealize this future role, without taking into account the practical implications of this responsibility.

Studies of recent years have investigated intercultural differences in perceptions of adult children's filial responsibility for caring for elderly parents. Thus, it was found that in both collectivist and traditional cultures such as those found in China and in Hong-Kong as well as in traditional societies the entire family is responsible for caring for elderly parents within the household (Ting \& Woo, 2009), rather than through an institutional arrangement (Al-Haj, 1995). Despite the effects of modernization processes on the Arab family structure and the Arab women, for the most part, it is the daughters and daughters-in-law, and occasionally the granddaughters, who in fact care for the elderly family member (Navaie-Waliser, Spriggs, \& Feldman, 2002).

Given this information, the research questions that emerge attempt to determine the relationship between the attitudes towards filial responsibility and the type of attachment style in adulthood and age (generation) among three generations of Jewish and Arab women. This, while taking into account demographic characteristics such education, religiosity etc., as well as the interpersonal variables of sense of mastery, self-esteem, and the intrapersonal variable of family support.

\section{Methods}

\subsection{Population and Sample}

The research participants were 63 Jewish and Arab university female students studying for an undergraduate or a graduate degree at the school of social work of Haifa University, Israel (the adult grandchildren generation), their parents (the adult parents generation, $\mathrm{N}=62$ ) and their grandparents (the elderly parents generation $\mathrm{N}=63$ ) reaching a total number of 188 participants. The sample was a convenience sample.

Each student was given a set of three identical questionnaires: one for self-use, one to be completed by a parent and one by a grandparent.

The age range of the adult grandchildren group was between 20 and 34 years old. The adult parents generation age range was between 38 - 57 years old, and in the elderly parents' generation, that of the grandparents, ages range from 60 to 83 years old. Additional demographic characteristics are presented in Table 1. 
Table 1. Background characteristics, interpersonal and intrapersonal variables of the three generations Jewish and Arab women $(\mathrm{N}=188)$.

\begin{tabular}{|c|c|c|c|c|c|c|c|c|c|c|c|c|}
\hline \multirow{2}{*}{ Variable } & \multicolumn{4}{|c|}{ Elderly Parents (N = 63) } & \multicolumn{4}{|c|}{ Adult Children $(\mathrm{N}=62)$} & \multicolumn{4}{|c|}{ Adult Grandchildren $(\mathrm{N}=63)$} \\
\hline & $\begin{array}{c}\text { Jewish } \\
(\mathrm{N}=38)\end{array}$ & $\mathrm{N} \%$ & $\begin{array}{c}\text { Arab } \\
(\mathrm{N}=25)\end{array}$ & $\mathrm{N} \%$ & $\begin{array}{c}\text { Jewish } \\
(\mathrm{N}=38)\end{array}$ & $\mathrm{N} \%$ & $\begin{array}{c}\text { Arab } \\
(\mathrm{N}=24)\end{array}$ & N\% & $\begin{array}{c}\text { Jewish } \\
(\mathrm{N}=38)\end{array}$ & N\% & $\begin{array}{c}\text { Arab } \\
(\mathrm{N}=25)\end{array}$ & N\% \\
\hline \multicolumn{13}{|l|}{ Family Status } \\
\hline Married/Living with a spouse & 37 & 97.3 & 22 & 88.0 & 35 & 92.1 & 23 & 92.0 & 12 & 31.5 & 17 & 77.2 \\
\hline Not Married/Living with a spouse & 1 & 2.7 & 3 & 12.0 & 3 & 7.9 & 1 & 8.0 & 26 & 68.5 & 8 & 22.8 \\
\hline \multicolumn{13}{|l|}{ Religiosity } \\
\hline Orthodox & - & - & 12 & 48.0 & - & - & 10 & 41.6 & - & - & 14 & 56.0 \\
\hline Conservative & 11 & 28.9 & 7 & 28.0 & 7 & 18.4 & 5 & 20.8 & 8 & 21.0 & 4 & 16.0 \\
\hline \multirow[t]{2}{*}{ Observant } & 27 & 71.1 & 6 & 24.0 & 31 & 81.6 & 9 & 37.6 & 30 & 79.0 & 7 & 28.0 \\
\hline & M & SD & M & SD & M & SD & M & SD & M & SD & M & SD \\
\hline Age (in years) & 70.1 & 10.11 & 63.2 & 8.70 & 52.7 & 6.22 & 44.5 & 9.23 & 26.8 & 6.08 & 22.9 & 2.83 \\
\hline Education (in years) & 11.9 & 4.42 & 6.9 & 3.04 & 14.8 & 3.74 & 11.4 & 2.22 & 14.6 & 1.53 & 13.9 & 1.99 \\
\hline Filial Responsibility 1 - 5 & 4.55 & 0.60 & 4.88 & 0.73 & 4.26 & 0.65 & 4.54 & 0.48 & 4.12 & 0.59 & 4.36 & 0.31 \\
\hline Attachment Avoidance type 1 - 7 & 3.20 & 0.88 & 3.14 & 0.41 & 3.65 & 0.74 & 3.24 & 0.48 & 3.86 & 0.46 & 3.28 & 0.30 \\
\hline Attachment Anxiety type 1 - 7 & 4.86 & 0.78 & 4.93 & 0.51 & 4.57 & 0.64 & 4.46 & 0.66 & 3.85 & 0.97 & 4.06 & 0.55 \\
\hline Sense of Mastery 1 - 5 & 3.74 & 1.01 & 3.97 & 0.76 & 3.52 & 1.13 & 4.17 & 0.66 & 4.63 & 0.57 & 4.48 & 0.70 \\
\hline Self-Esteem 1 - 5 & 3.50 & 0.81 & 3.83 & 0.57 & 4.02 & 0.63 & 3.96 & 0.38 & 4.25 & 0.46 & 4.14 & 0.72 \\
\hline Family Support 1 - 7 & 5.11 & 1.24 & 5.77 & 0.83 & 5.61 & 0.99 & 5.92 & 0.77 & 6.11 & 0.81 & 6.25 & 0.89 \\
\hline
\end{tabular}

${ }^{*}$ Arab $=$ Christian, Muslim and Druze.

\subsection{Research Tools}

Attitudes towards filial responsibility: was measured using The Expectations of Filial Responsibility Scale developed by Hamon and Blieszner (1990). This questionnaire contains 16 items that describe filial behaviors of adult children towards his/her parents. Participants are asked to rank the degree to which they agree with the statements, using, on a Likert-like scale ranging from 1 = "completely disagree" to 5 = "very much agree". The current study used the version of van der Pas, Van Tilburg, \& Knipscheer, 2005. The tool's reliability in the current study was between 0.90 and 0.91 Cronbach's alpha for the three participating generations.

Type of attachment: was examined using the questionnaire of Brennan et al. (1998): Experiences in Close Relationships (ECR) Scale. The questionnaire was translated into Hebrew by Mikulincer \& Florian (2000). It includes 36 items, which create two scales representing the two dimensions: anxiety (18 items, e.g., "I'm afraid of being abandoned") and avoidance (18 items, e.g., "I prefer not to let other people know how I feel inside"). Participants are asked to rank the degree to which they agree with the statement, using a seven-point Likert-like scale ranging from $1=$ "disagree completely" to 7 = "agree completely". Two scores are calculated for each of the participants: one for the anxiety dimension and one for the avoidance dimension, so that a high score indicates an attachment style characterized by a high degree of anxiety or avoidance. The reliability of this tool in the current study was between 0.81 and 0.86 Cronbach's alpha for the avoidance dimension, and between .88 and .91 Cronbach's alpha for the anxiety dimension, for participants from all three generations.

Sense of Mastery: was measured using the scale of Pearlin \& Schooler (1978), which was translated into Hebrew and validated by Hobfoll \& Walfisch (1984). The scale includes seven items, on which participants indicate the degree to which they agree with the given statements: $1=$ strongly disagree and $5=$ strongly agree. A high average score indicates a strong sense of mastery. Reliability of the original scale was 0.79 Cronbach's alpha, whereas in the current study, internal reliability was 0.81 Cronbach's alpha.

Self-esteem: was measured using the Rosenberg (1965) scale of self-esteem. The questionnaire consists of ten 
items, ranked on a Likert-like scale ranging from 1 = disagree completely, to 5 = agree completely. Five of the items relate to positive feelings regarding self-esteem, such as "I feel I have several good qualities", and five items relate to negative feelings regarding self-esteem, such as "in general, I tend to consider myself a failure". The overall ranking is calculated according to the item averages, such that a high ranking corresponds to a high level of self-esteem. The questionnaire was translated into Hebrew by Hobfoll and Walfisch (1984), who reported reliability rates between 0.81 Cronbach's alpha and 0.90 Cronbach's alpha.

Familial support: This variable was measured using the Multi-Dimensional Scale of Perceived Social Support (MS PSS), which was introduced by Zimet, Dahlem, Zimet \& Farley (1988) to measure familial support. The scale includes 12 items referring to three sources of support: family, friends, and significant others. In the current study, only the section on familial support was used. On each item, participants are asked indicate the degree to which the statement corresponds to their feelings, using a seven-point Likert-like scale ranging from $1=$ "extremely different from the way I feel”, to 7 = "closely corresponds to the way I feel”. Participants' scores were calculated as the average of rankings for all items. Reliability of this scale in the current study was between 0.90 and 0.93 Cronbach’s alpha, for participants from all three generations.

\subsection{Procedure}

The current study was approved by the Ethics Committee of Haifa University. The goals of the study were explained to the students, and they all signed an informed consent form, which included a written description of the research, its aims and significance, as well as anonymity and confidentiality clauses. Most of the study participants answered the questioner by themselves, only few elderly participants (3 elderly Arab and 1 Jewish elderly) needed to get help from family members to fulfill it. Trios of three generations questionnaires that did not included in the current study were from reasons such: One generation member in the family wouldn't agree to participant in the study; the questionnaires did not come back completely finished by one or more of the generations. At the end, the study included 63 (except the adult parent generation $\mathrm{N}=62$ ) treads generations families, e.g. 188 participants.

All questionnaires were translated to Arabic and then the accuracy of the translation was verified using the back-translation method. The questionnaires were completed using the self-report method: hence, and when necessary, the youngest generation members helped their older relatives understand the questions.

\section{Results}

Demographic statistics, frequency distribution, means and SDs of the research variables were analyses by using SPSS 19. Results are shown in Table 1.

Findings indicated that the adult grandchild generation is the most educational generation, and have the largest number of orthodox participants. This generation also assigned higher ranking on the variables of sense of mastery, self-esteem, and family support, than did the adult parents' generation, and that the adult parent's generation's rankings were higher than those of the elderly parents' (grandparents) generation. In terms of attitudes towards filial responsibility, the highest scores were found among the elderly parents' generation.

To assess whether there are associations between the attitudes towards filial responsibility, interpersonal variables (sense of mastery, self-esteem), and the intrapersonal variable (family support), and the two attachment styles variables (anxiety type and avoidance type-ordinal variables) Pearson and Spearman correlations tests for the entire sample were conducted. Results are shown in Table 2.

Finding show significant correlations between most of the research variables. To assess the correlations between the two attachment styles' variables among the three generations (anxiety type and avoidance type) chi square test were conduct. A significant connection was found between the generation and the attachment style: Higher frequency of anxiety style of attachment was found among the adult grandchildren generation while among the adult parent and the elderly parent higher frequency of avoidance style of attachment was found $\left(\mathbf{X}^{2}\right.$ $=16.54, p<0.01$ ). A Repeated measures ANOVA has shown significant differences between the three generations regarding the attitudes towards filial responsibility $\left[\mathrm{F}_{(2,076)}=5.64, p<0.01\right]$. Continuers' procedure of LSD reviled that the elderly parent generation had the highest level of attitudes towards the filial responsibility.

The assumption that differences will be found between the Jewish and the Arab three generations regarding the attitudes towards filial responsibility dividing into the two attachment styles was measured by two factors analysis. Findings are shown in Table 3. 
Table 2. Pearson and Spearman correlations between attachment style and attitudes toward filial responsibility, interpersonal and intrapersonal Variables (the all sample).

\begin{tabular}{lccccccccc}
\hline \multicolumn{1}{c}{ Variables } & 1 & 2 & 3 & 4 & 5 & 6 & 7 & 8 \\
\hline 1) Filial Responsibility & 1 & $0.62^{* *}$ & $-0.39^{* *}$ & $0.26^{*}$ & $0.58^{* *}$ & $0.33^{*}$ & 0.38 & 0.17 \\
2) Avoidance Attachment style & - & 1 & -0.19 & $0.32^{* *}$ & $0.36^{*}$ & $0.63^{*}$ & 0.11 & $0.57^{*}$ \\
3) Anxiety Attachment style & - & - & 1 & $-0.43^{* *}$ & $-0.28^{*}$ & $-0.40^{*}$ & -0.11 & $-0.60^{*}$ \\
4) Sense of Mastery & - & - & - & 1 & $0.24^{* *}$ & $0.41^{* *}$ & 0.14 & $0.22^{*}$ \\
5) Self-Esteem & - & - & - & - & 1 & $0.29^{*}$ & 0.32 & $0.36^{*}$ \\
6) Family support & - & - & - & - & - & 1 & 0.20 & 0.24 \\
7) Education & - & - & - & - & - & - & 1 & 0.08 \\
8) Age & - & - & - & - & - & - & - & 1 \\
\hline
\end{tabular}

Table 3. Two factors analysis, Means and Standard deviations of attitudes towards filial responsibility by distribution to ethnicity and attachment style.

\begin{tabular}{|c|c|c|c|c|c|c|c|}
\hline Generation & Ethnicity & Attachment style & $\mathrm{N}$ & M & SD & F & \\
\hline \multirow{9}{*}{ Elderly parent } & \multirow{3}{*}{ Arab } & Avoidance & 17 & 3.14 & 0.41 & & \\
\hline & & Anxiety & 8 & 4.93 & 0.51 & & \\
\hline & & Total & 25 & 4.07 & 0.45 & & \\
\hline & \multirow{3}{*}{ Jewish } & Avoidance & 28 & 3.20 & 0.88 & & \\
\hline & & Anxiety & 10 & 4.86 & 0.78 & & \\
\hline & & Total & 38 & 4.55 & 0.83 & & \\
\hline & \multirow{3}{*}{ Total } & Avoidance & 45 & 3.19 & 0.60 & Ethnicity & $8.58^{* *}$ \\
\hline & & Anxiety & 18 & 4.90 & 0.63 & Attachment style & $2.63^{*}$ \\
\hline & & Total & 63 & 4.39 & 0.71 & Interaction effect & $3.70^{*}$ \\
\hline \multirow{9}{*}{ Adult parent } & \multirow{3}{*}{ Arab } & Avoidance & 15 & 3.24 & 0.48 & & \\
\hline & & Anxiety & 9 & 4.46 & 0.66 & & \\
\hline & & Total & 24 & 4.03 & 0.57 & & \\
\hline & \multirow{3}{*}{ Jewish } & Avoidance & 20 & 3.65 & 0.74 & & \\
\hline & & Anxiety & 18 & 4.57 & 0.64 & & \\
\hline & & Total & 38 & 4.12 & 0.69 & & \\
\hline & \multirow{3}{*}{ Total } & Avoidance & 35 & 3.33 & 0.50 & Ethnicity & $7.17^{* *}$ \\
\hline & & Anxiety & 27 & 4.54 & 0.66 & Attachment style & $3.05^{*}$ \\
\hline & & Total & 62 & 4.50 & 0.69 & Interaction effect & $0.18^{*}$ \\
\hline \multirow{9}{*}{ Adult grandchildren } & \multirow{3}{*}{ Arab } & Avoidance & 11 & 3.28 & 0.30 & & \\
\hline & & Anxiety & 14 & 4.46 & 0.55 & & \\
\hline & & Total & 25 & 3.77 & 0.43 & & \\
\hline & \multirow{3}{*}{ Jewish } & Avoidance & 27 & 3.06 & 0.46 & & \\
\hline & & Anxiety & 11 & 4.68 & 0.97 & & \\
\hline & & Total & 38 & 4.12 & 0.72 & & \\
\hline & \multirow{3}{*}{ Total } & Avoidance & 38 & 3.37 & 0.60 & Ethnicity & $6.99^{*}$ \\
\hline & & Anxiety & 25 & 4.69 & 0.80 & Attachment style & $2.12^{*}$ \\
\hline & & Total & 63 & 3.26 & 0.40 & Interaction effect & $3.16^{*}$ \\
\hline
\end{tabular}

${ }^{*} p<0.05 ;{ }^{* *} p<0.01$. 
Ethnicity differences were found among all three generations: The Arab women were found to be with higher positive attitudes toward filial responsibility than the Jewish women were. Differences were also found regarding the attachment style and the filial responsibility so that among both the Jewish and the Arab two eldest generations' women the avoidance style of attachment was the most frequent. Among the adult grandchildren generation the anxiety style of attachment was fund to be the most frequent.

The research finding has shown that several variables were found to be associated to the anxiety and avoidance types of attachments such religiosity, family support, sense of mastery and, self-esteem. In the next step two Multiple Regressions were conducted: the dependent variables were the avoidance and the anxiety types of attachment (the dependent variable in the first Multiple Regressions was the avoidance type of attachment and, in the second Multiple Regressions it was the anxiety type of regression. The five variables mentioned above were entered into the regressions as possible predictors to the attitude toward the filial responsibility among the three generations of women. The findings are shown in Table 4.

As the table shows the dependent variable at the first multiple regression was the anxiety type of attachment in adulthood. Among the elderly parents women generation $11 \%$ of the explained diversity in the anxiety attachment style was predicted by the model variables. Yet, the model was not found to be significant $(F(7.46)=$ 0.31 , n.s.). Among the adult parent generation, $23 \%$ of the explained diversity in the anxiety attachment style was predicted by the model variables which was not fund to be significant $(F(7.46)=2.21$, n.s.). Among the adult grandchildren generation, $52 \%$ of the explained diversity in the anxiety attachment style was predicted by the model variables which was fund to be significant $(\mathrm{F}(7.47)=5.20, p<0.001)$.

The dependent variable in the second multiple regression which was conducted was the avoidance type of attachment. Among the elderly parents generation $35 \%$ of the explained diversity in the anxiety attachment style was predicted by the model variables and the model was found to be significant $(\mathrm{F}(7.46)=3.27, p<0.05)$. Among the adult parent generation, $44 \%$ of the explained diversity in the anxiety attachment style was predicted by the model variables which was fund to be significant (F (7.46) $=3.78, p<0.05)$. Among the adult grandchildren generation, $52 \%$ of the explained diversity in the anxiety attachment style was predicted by the model variables which was fund to be significant $(\mathrm{F}(7.47)=2.52$, n.s. $)$.

\section{Discussion}

The current study attempted to examine the relationship between attitudes towards filial responsibility and the attachment style among Jewish and Arabs three generations of women in the Northern of Israel.

Findings revealed intergenerational differences, such that the oldest women generation was the one with the strongest positive attitudes related to filial responsibility, as compared to those of the other two generations. This finding was especially higher among the three generations of Arab women. The simplest explanation for this result is the issue of age. The older a person gets, the more aware he/she becomes of the possibility that sometime in the future one may need the help of others, and that family members are the natural candidates for providing this

Table 4. Multiple regression analysis predicting filial responsibility according the style of attachment in adulthood.

\begin{tabular}{|c|c|c|c|c|c|c|}
\hline & \multicolumn{2}{|c|}{ Elderly Parents } & \multicolumn{2}{|c|}{ Adult Parents } & \multicolumn{2}{|c|}{ Adult Grandchildren } \\
\hline & $\begin{array}{c}\text { Anxiety style } \\
\beta\end{array}$ & $\begin{array}{c}\text { Avoidance style } \\
\beta\end{array}$ & $\begin{array}{c}\text { Anxiety style } \\
\beta\end{array}$ & $\begin{array}{c}\text { Avoidance style } \\
\beta\end{array}$ & $\begin{array}{c}\text { Anxiety style } \\
\beta\end{array}$ & $\begin{array}{c}\text { Avoidance style } \\
\beta\end{array}$ \\
\hline Ethnicity & -0.54 & $0.39^{* *}$ & -0.19 & $0.21^{* *}$ & $0.38^{*}$ & -0.20 \\
\hline Religiosity & -0.31 & $0.54^{* *}$ & -0.16 & $0.18^{*}$ & $0.19^{*}$ & -0.62 \\
\hline Self-Esteem & -0.46 & $0.42^{*}$ & -0.05 & $0.21^{* *}$ & $0.33^{* * *}$ & -0.08 \\
\hline Sense of Mastery & -0.22 & 0.19 & -0.20 & $0.14^{* *}$ & $0.47^{* *}$ & -0.12 \\
\hline Family Support & -0.18 & $0.40^{*}$ & -0.33 & $0.16^{*}$ & $0.20^{* *}$ & -0.11 \\
\hline \multicolumn{7}{|l|}{ Multiple } \\
\hline $\mathrm{R} 2$ & 0.11 & 0.35 & 0.23 & 0.44 & 0.52 & 0.39 \\
\hline $\mathrm{F}$ & $F(7,46)=0.51$ & $\mathrm{~F}(7,46)=3.27^{* *}$ & $F(7,46)=2.21$ & $F(7,46)=3.78^{* *}$ & $\mathrm{~F}(7,47)=5.20^{* * * *}$ & $F(7,47)=2.52$ \\
\hline
\end{tabular}

${ }^{*} p>0.01 ;{ }^{* *} p<0.05 ;{ }^{* * * *} p<0.001$. 
assistance (Fingerman, Sechrist, \& Birditt, 2013). Another explanation emphasizes the phenomenon of filial responsibilities among family members in traditional societies. In general, the head of traditional family, including the Arab family, is the eldest male figure (grandparent, parent, uncle etc.). A comprehensive study conducted among Arab families in Israel found that adult children's filial responsibility towards their parents was very high (Halayla, 2008). The researcher found that despite processes of urbanization, modernization, and offspring's exodus from the villages in search of employment, filial responsibility of Arab participants in terms of caring for elderly parents was relatively high compared to that demonstrated in other studies involving Jewish participants. This was particularly true about Muslim Arabs (compared to Christian Arabs and Druse) and religious (compared to secular) participants living in northern Israel. The Palestinian sociologist Sharabi (1992) argues that over the past century they have not changed and repaired infrastructure of the patriarchal Arab culture. Those norms, among other norms, included the feminine women members' role in the family. Women can never be the head of the clan even when she is educated and extremely wised. Her role is to take care for the family members and to the elderly and the vulnerable members among them. Those long years of tradition might have their influence on the way attitudes towards filial responsibility are intergenerational transmitted.

Another finding in the current study that demonstrated an intergenerational difference was in the relationship between the attachment style and the attitudes towards filial responsibility. It was found that those generations' members with the avoidance attachment style exhibited the strongest positive attitudes regarding filial responsibility. Also here, the majority of participants with this attachment style belong to the women from the elderly parents' generation.

Given that there are only a few studies on the attachment styles of the elderly (perhaps because their attachment figures have already passed on), and poorly studies involving women attachment styles, it is possible that the explanation offered in Cicirelli's (1993) study regarding the elderly parents generation could be pertinent in his study. Cicirelli drew a distinction between attachments and affection, and claimed that "although they are related, attachment and affection are not synonymous concepts. Nevertheless, most existing studies of adult attachment in relation to caregiving have used measures of affection to represent attachment” (1993: p. 145). In the current study, the findings of significant correlation between avoidance attachment style and high positive level attitudes towards filial responsibility in the elderly parents' generation can be used as an attempted to expand Cicirelli's idea and offer an explanation that relates to the absence of a live attachment figure among the eldest generation. Thus, it is suggested that the demise of the attachment figure and the continued feelings towards such a figure, it is possible that the women of the elderly parent generation shifted the feelings they had for their attachment figures onto their offspring. This shift is manifested in the way that they express emotions towards their children or in their attitudes towards filial responsibility. Clearly, this explanation must be examined in future studies.

The literature does not provide any certain differences between men and women regarding to the attachment styles in adulthood. A little attention to women attachment style was given for emphasizing the association between an attachment style and mental health issues such early separation anxiety in women with eating disorders (Trois, Massaroni, \& Cuzzlaro, 2005), clinical depression (Bifulco, Moran, Ball, \& Bernazzani, 2002), adjustment in men and women with HIV/AIDS (Turner-Cobb et al., 2002) etc. As noted in the literature review, the patterns of attachment are based on mental representations, positive and negative of the self and of the other, which are located on a continuum that includes the dimensions of avoidance and anxiety (Bartholomew \& Horowitz, 1991; Brennan et al., 1998). Those men and/or women with an anxiety attachment style are characterized by a positive attitude towards self and others, whereas those with an avoidance attachment style demonstrate a more positive attitude towards the other than towards the self. In an attempt to explain the effect identified in the study, a comparison between these two attachment styles is warranted. The common denominator between the two attachment styles is a positive attitude towards the other, which enables the development of intimacy, and a dependence on the other, and thus there is no avoidance of closeness. Nonetheless, among those with an anxiety attachment style, this closeness is the outcome of despair and separation anxiety (Bartholomew \& Horowitz, 1991). This positive perception of the other coincides with the higher scores that participants with this attachment style indicated on the avoidance dimension. It is possible that a positive perception of the other may explain the stronger attitudes towards filial responsibility indicated by participants with this attachment type.

The difference between those with an anxiety attachment style and those with the avoidance attachment style is in their perception of self and the levels of anxiety they demonstrate. While those with an anxiety attachments style demonstrate high levels of self-esteem and a positive self-perception, those with the avoidance attachment 
style demonstrate low self-esteem and a negative sense of self, which is reinforced by the people in their surroundings (Brennan et al., 1998; Sörensen et al., 2002). This self-perception may explain the manner in which their dependence on others is perceived as a source of security, characterized by a desperate need for attention (Grundy \& Henrietta, 2006; Merz, Schuengel, \& Schulzem, 2008).

As the individual matures, and the need for closeness and contact with the attachment figure becomes more symbolic, a situation of distress is likely to cause this person to turn to the attachment figure. Providing assistance to the parents is considered a protecting behavior. Whether the assistance is limited to the conceptual level, as in feelings, a sense of filial responsibility or it is manifested in practice-and perhaps constitutes a burden, the very act of providing such assistance enables the adult child to protect the attachment figure from danger. In this context, strong positive attitudes towards filial responsibility may reflect the attempts of adult children with an anxiety attachment style to preserve their source of security and diminish their fear of separation (Karantzas et al., 2010).

Regarding the motives for caring for an elderly parent, it was indicated that care provided by an individual with an anxiety attachment style derives from self-focused anxiety regarding the shift of attention from self to the attachment figure (Feeney \& Hohaust, 2001; Collins \& Feeney, 2000). Those findings have shown a motivation for caregiving based on egotistical considerations, given the limited ability of those with anxiety attachment style to provide support, which requires a degree of empathy for others. The gap between attitudes and actual caring behavior may explain the current study's finding of particularly strong positive attitudes towards filial responsibility among individuals with anxiety attachment styles. Similarly, future studies may be able to determine whether mediating variables also affect (and if so, to what extent) the willingness of those with an avoidance attachment style to provide future care for the elderly relative. The mentioned gap between attitudes to filial responsibility and the actual provision of care in fulfilling this filial responsibility may be explained by referring to the participants' age: in the case of young adults, the need to act on their attitudes is still distant and they may have an idealized view of this task, without fully understanding the implications of this responsibility (Silverstein \& Gans, 2006).

The impact of the variable of ethnicity on filial norms and caring for older parents has been widely investigated in the literature (Pinquart \& Sörensen, 2006; Connidis, 2003; Sung, 1998; Lowenstein \& Katz, 2000). In traditional Arab society — and to some extent this has not changed - the extended family functions as a single system, a clan, a collective structure in which the group or family identity plays a central role (Barakat, 1993). According to the collectivist norms of Arab society, especially among the Muslim society, the children (mostly daughters and daughters in low) are responsible for caring for their elderly parents; this manifests in the existence of a broad family network that supports and keeps its elderly members within the home (Halayla, 2008).

In the current study, the religiosity was found to be one of the predictors of the positive attitudes towards the filial responsibility among the three generations members especially among the elderly parents generation. It seems that among the Israeli Arab-Muslim society, practicing the religion is a major factor in the family life and to take care for an elderly parent in a social norm as well as a religion norm.

Findings of the current study are supported by an additional study which recently examined the role of intergenerational solidarity and filial norms and its effect on quality of life, while comparing a cohort of adult Jews and adult Arabs in Israel (Katz \& Lowenstein, 2012). When caring for an elderly parent, families of both ethnicities face the same challenges, although the ways in which families cope and the solutions that they find tend to differ. Katz \& Lowenstein found that Arab adults are more likely to receive support from their family members in the hour of need, because of the family structure, the norms, and the social, religious and financial resources. The comparison regarding the variable of intergenerational solidarity and support for an elderly parent revealed various similarities and differences, which are related to the culture and to family values, as well as to the personal resources.

Another interesting finding pertaining to the three generations members especially the youngest generation was a positive relationship between family support and attitudes towards filial responsibility. These findings somehow distinguish the adult grandchildren generation from their parents and grandparents, thus begging the question of what causes these differences. One of the popular explanations for this phenomenon is related to the modernization process, which was emphasized earlier (Campbell \& Martin-Matthews, 2003). This effect is the outcome of the rise in life expectancy, the increased percentage of physically limited elderly people, the fracturing of the extended family into independent nuclear families, the more limited availability of women as caregivers, due to their involvement in education and in the employment market, as well as the strengthening of the status of 
youth in society (Al-Haj, 1995; Hsu, Lew-Ting, \& Wu, 2001).

Yet, it seems that in last two decades, the younger generation is getting closer to their extend families socially and emotionally. It may be because of the need to balancing between the competitive-cold-world outside and the supportive-cozy-world within the family. It may be connected to the fact that young people from the three monotheistic religions are becoming closer to their religion all over the world and actually, we can see a parallel process of modernization on the one hand and getting back to tradition and old norms on the other hand.

The main limitation of the current study is the convenient sampling and from two reasons: the first reason is that all of the grandchildren generations were university students. This fact can have some influence on their general attitudes toward family relations at all and toward filial responsibilities in particular. People who get higher education may come from different families of those who do not. The second reason relates to the area of Northern Israel from which most of the participants were from. It may be assumed that in other Israeli areas the three generation family participant will held on different attitudes toward filial responsibility.

\section{References}

Al-Haj, M. (1995). Kinship and Modernization in Developing Societies: The Emergence of Instrumentalized Kinship. Journal of Comparative Family Studies, 26, 311-328.

Baltes, P. B., \& Graf, P. (1996). Psychological Aspects of Aging: Facts and Frontiers. In D. Magnusson (Ed.), The Life Span Development of Individuals: Behavioural, Neurobiological and Psychosocial Perspectives (pp. 427-459). Cambridge, England: Cambridge University Press.

Barakat, H. (1993). The Arab World: Society, Culture, and State. Oakland, CA: University of California Press.

Bartholomew, K., \& Horowitz, L. M. (1991). Attachment Styles among Young Adults: A Test of a Four-Category Model. Journal of Personality and Social Psychology, 61, 226-244. http://dx.doi.org/10.1037/0022-3514.61.2.226

Barusch, A.S., \& Spaid, W. M. (1989). Gender Differences in Caregiving: Why Do Wives Report Greater Burden? Gerontologist. 29, 667-676. http://dx.doi.org/10.1093/geront/29.5.667

Bifulco, A., Moran, P. M., Ball, C., \& Bernazzani, O. (2002). Adult Attachment Style: Its Relationship to Clinical Depression. Social Psychiatry and Psychiatric Epidemiology, 37, 50-59. http://dx.doi.org/10.1007/s127-002-8215-0

Blenkner, M. (1965). Social Work and Family Relationships in Later Life with Some Thoughts on Filial Maturity. In E. Shanas, \& G. F. Streib (Eds.), Social Structure and the Family: Generational Relations (pp. 117-130). Englewood Cliffs, NJ: Prentice Hall.

Brennan, K. A., Clark, C. L., \& Shaver, P. R. (1998). Self-Report Measurement of Adult Attachment: An Integrative Overview. In J. A. Simpson, \& W. S. Rholes (Eds.), Attachment Theory and Close Relationships (pp. 46-76). New York: Guilford.

Campbell, L. D., \& Martin-Matthews, A. (2003). The Gendered Nature of Men’s Filial Care. Journal of Gerontology: Social Sciences, 58, 350-358. http://dx.doi.org/10.1093/geronb/58.6.S350

Carpenter, B. C. (2001). Attachment Bonds between Adult Daughters and Their Older Mothers: Associations with Contemporary Caregiving. Journal of Gerontology: Psychological Sciences, 56, 257-266. http://dx.doi.org/10.1093/geronb/56.5.P257

Chappell, N. L., \& Reid, R. C. (2002). Burden and Well-Being among Caregivers: Examining the Distinction. Gerontologist, 42, 772-780. http://dx.doi.org/10.1093/geront/42.6.772

Cicirelli, V. G. (1988). A Measure of Filial Anxiety Regarding Anticipated Care of Elderly Parent. The Gerontologist, 28, 478-482. http://dx.doi.org/10.1093/geront/28.4.478

Cicirelli, V. G. (1993). Attachment and Obligation as Daughters' Motives for Caregiving Behavior and Subsequent Effect on Subjective Burden. Psychology and Aging, 8, 144-155. http://dx.doi.org/10.1037/0882-7974.8.2.144

Cicirelli, V. G. (2010). Relation of Educational Level, Internality, and Health Status to Older Adults' Self Health Care. The 63rd Annual Scientific Meeting of the Gerontological Society of America, New Orleans, LA, 16 March 2010, 1-14.

Cohen, S., \& Wills, T. (1985). Stress, Social Support and the Buffering Hypothesis. Psychological Bulletin, 98, 310-357. http://dx.doi.org/10.1037/0033-2909.98.2.310

Collins, N. L., \& Feeney, B. C. (2000). A Safe Haven: An Attachment Theory Perspective on Support Seeking and Caregiving in Intimate Relationships. Journal of Personality and Social Psychology, 78, 1053-1073.

http://dx.doi.org/10.1037/0022-3514.78.6.1053

Feeney, J. A., \& Hohause, L. (2001). Attachment and Spousal Caregiving. Personal Relationships, 8, 21-39. http://dx.doi.org/10.1111/j.1475-6811.2001.tb00026.x

Fingerman, K. L., Sechrist, J., \& Birditt, K. S. (2013). Changing Views on Intergenerational Ties. Gerontology, 59, 64-70. http://dx.doi.org/10.1159/000342211 
Gillath, O., Shaver, P. R., Mikulincer, M., Nitzberg, R. E., Erez, A., \& Van Ijzendoorn, M. H. (2005). Attachment, Caregiving and Volunteering: Placing Volunteerism in an Attachment-Theoretical Framework. Personal Relationships, 12, 425446. http://dx.doi.org/10.1111/j.1475-6811.2005.00124.x

Grundy, E., \& Henrietta, J. C. (2006). Between Elderly Parents and Adult Children: A New Look at the Intergenerational Care Provided by the "Sandwich Generation". Ageing \& Society, 26, 707-722. http://dx.doi.org/10.1017/S0144686X06004934

Halayla, R. (2008). Modernization and Filial Piety towards Elderly Parents in Arab Society in Israel. Ph.D. Dissertation, Jerusalem: Hebrew University of Jerusalem. (In Hebrew)

Hamon, R. R.,\& Blieszner, R. (1990). Filial Responsibility Expectations among Adult Children-Older Parent Pairs. Journal of Gerontology, 45, 110-112. http://dx.doi.org/10.1093/geronj/45.3.P110

Hobfoll, S. E. (1996). Social Support: Will You Be There When I Need You? In N. Vanzetti, \& S. Duck (Eds.), A Lifetime of Relationships (pp. 46-74). Belmont, CA: Thomson Brooks/Cole Publishing Co.

Hobfoll, S. E., \& Walfisch, S. (1984). Coping with a Threat to Life: A Longitudinal Study of Self-Concept, Social Support, and Psychological Distress. American Journal of Community Psychology, 12, 87-100. http://dx.doi.org/10.1007/BF00896930

Hsu, H.-C., Lew-Ting, C. Y., \& Wu, S.-C. (2001). Age, Period and Cohort Effects on the Attitude toward Supporting Parents in Taiwan. The Gerontologist, 41, 742-750. http://dx.doi.org/10.1093/geront/41.6.742

Karantzas, G. C., Evans, L., \& Foddy, M. (2010). The Role of Attachment in Current and Future Parent Caregiving. The Journals of Gerontology. Series B, 65B, 573-580. http://dx.doi.org/10.1093/geronb/gbq047

Katz, R., \& Lowenstein, A.(2012). Rethinking Theoretical and Mythological Issues in Intergenerational Family Relations Research. Ageing and Society, 31, 1077-1083.

Krause, A. M., \& Haverkamp, B. E. (1996). Attachment in Child-Older Parent Relationships: Research, Theory, and Practice. Journal of Counseling \& Development, 75, 83-92. http://dx.doi.org/10.1002/j.1556-6676.1996.tb02318.x

Lachman, M. E., \& Weaver, S. L. (1998). The Sense of Control as Moderator of Social Class Differences in Health and Well-Being. Journal of Personality and Social Psychology, 74, 763-773. http://dx.doi.org/10.1037/0022-3514.74.3.763

Lowenstein, A., \& Kats, R. (2000). Rural Arab Families Coping with Cargiving. Marriage \& Family Review, 30, $179-197$. http://dx.doi.org/10.1300/J002v30n01 11

Merz, E. M., Schuengel, C., \& Schulze, H. J. (2008). Inter-Generational Relationships at Different Ages: An Attachment Perspective. Ageing and Society, 28, 717-736. http://dx.doi.org/10.1017/S0144686X08007046

Mikulincer, M., \& Florian, V. (2000). Exploring Individual Differences in Reactions to Mortality Salience: Does Attachment Style Regulate Terror Management Mechanisms? Journal of Personality and Social Psychology, 79, 260-273. http://dx.doi.org/10.1037/0022-3514.79.2.260

Mikulincer, M., \& Shaver, P. R. (2007). Attachment Patterns in Adulthood: Structure, Dynamics and Change. New York: Guilford Press.

Navaie-Waliser, M., Spriggs, A., \& Feldman, P. H. (2002). Informal Caregiving: Differential Experiences by Gender. Medical Care, 40, 1249-1259. http://dx.doi.org/10.1097/00005650-200212000-00012

Pearlin, L. I. (1999). The Stress Process Revisited: Reflections on Concepts and Their Interrelationships. In C. S. Aneshensel, \& J. C. Phelan (Eds.), Handbook of the Sociology of Mental Health (pp. 395-415). New York: Springer. http://dx.doi.org/10.1007/0-387-36223-1 19

Pearlin, L. I., \& Schooler, C. (1978). The Structure of Coping. Journal of Health and Social Behavior, 19, 2-21. http://dx.doi.org/10.2307/2136319

Pinquart, M., \& Sörensen, S. (2006). Gender Differences in Caregiver Stressors, Social Resources, and Health: An Updated Meta-Analysis. The Journals of Gerontology. Series B, 61, 33-45. http://dx.doi.org/10.1093/geronb/61.1.P33

Ron, P. (2009). Daughters as Caregivers of Aging Parents: The Shattering Myth. Journal of Gerontological Social Work, 52, 135-153. http://dx.doi.org/10.1080/01634370802561943

Rosenberg, M. (1965). Society and the Adolescent Self-Image. Princeton, NJ: Princeton University Press.

Silverstein, M., \& Gans, D. (2006). Intergenerational Support to Aging Parents: The Role of Norms and Needs. Journal of Family Issues, 27, 1068-1084. http://dx.doi.org/10.1177/0192513X06288120

Skaff, M., Pearlin, L. I., \& Mullen, J. T. (1996). Transitions in Caregiving Career: Effects on Sense of Mastery. Psychology and Aging, 11, 247-257. http://dx.doi.org/10.1037/0882-7974.11.2.247

Sörensen, S., Webster, J. D., \& Roggman, L. A. (2002). Adult Attachment and Preparing to Provide Care for Older Relatives. Attachment \& Human Development, 4, 84-106. http://dx.doi.org/10.1080/14616730210123102

Sung, K. T. (1998). Exploration of Action of Filial Piety. Journal of Aging Studies, 12, 369-386. http://dx.doi.org/10.1016/S0890-4065(98)90025-1 
Ting, G. H. Y., \& Woo, J. (2009). Elder Care: Is Legislation of Family Responsibility the Solution? Asian Journal of Gerontology and Psychiatry, 4, 72-75.

Trois, A., Massaroni, P., \& Cuzzlaro, M. (2005). Early Separation Anxiety and Adult Attachment Style in Women with Eating Disorders. British Journal of Clinical Psychology, 44, 89-97.

Troll. L. E., Miller, S. J., \& Achely, R. C. (1979). Families in Later Life. Belmont, CA: Wadsworth.

Turner-Cobb, J., Gore-Felton, C., Marouf, F., Koopman, C. et al. (2002). Coping, Social Support and Attachment Style as Psychosocial Correlates of Adjustment in Men and Women with HIV/AIDS. Journal of Behavioral Medicine, 25, 337-353. http://dx.doi.org/10.1023/A:1015814431481

Van der Pas, S., Van Tilburg, T. G., \& Knipscheer, C. P. M. (2005). Measuring Older Adults’ Filial Responsibility Expectations: Exploring the Applications of a Vignette Technique and an Item Scale. Educational and Psychological Measurement, 65, 1026-1045. http://dx.doi.org/10.1177/0013164405278559

Zimet, G. D., Dahlem, N. W., Zimet, S. G., \& Farey, G. K. (1988). The Multidimensional Scale of Perceived Social Support. Journal of Personality Assessment, 52, 30-41. http://dx.doi.org/10.1207/s15327752jpa5201_2 